Nicola Jägers*

\title{
National Human Rights Institutions: The Missing Link in Business and Human Rights Governance?
}

https://doi.org/10.1515/icl-2020-0006

\begin{abstract}
In 2014, the United Nations established a working group to elaborate an international treaty on business and human rights. In October 2018, negotiations on a first draft of the actually text took place. Besides this zero-draft, the working group released the draft text of an Optional Protocol containing several institutional arrangements. The Optional Protocol carves out a key role for national implementation mechanisms to promote compliance with, monitor and implement the treaty on business and human rights. With such an institutional arrangement, the future treaty would join the ranks of what can be called a new generation of human right treaties which institutionalize a top down with a bottom up approach aiming to address the disjuncture between rules and practice. The Optional Protocol indicates that this role of national implementation mechanism could be taken up by National Human Rights Institutions (NHRIs). This follows an increased recognition of NHRIs as significant actors in the business and human rights domain. Yet, the role of NHRIs in human rights governance in general, and in the business and human rights field in particular, is not yet well understood and undertheorized. The aim of this article is to add insight into the role of NHRIs in business and human rights by, first, describing some of the current activities undertaken by NHRIs in this field in order to analyze whether the role ascribed to them is actually being taken up and what challenges NHRIs face. From this perspective, it will be discussed whether the role foreseen in the Optional Protocol of the future business and human rights treaty holds promise.
\end{abstract}

Keywords: human rights, business, treaty, National Human Rights Institutions (NHRIs), experimental governance, new governance

\footnotetext{
Nicola Jägers holds the Chair of International Human Rights Law at Tilburg University, the Netherlands. She is also Commissioner at the Netherlands Human Rights Institute, the official NHRI. This article was written in a personal capacity and nothing in this article reflects the opinion of the Netherlands Human Rights Institute. All comments welcome: nicola.jagers@uvt.nl
}

*Corresponding author: Nicola Jägers, Department of Public Law and Governance, Tilburg University Faculty of Law, Tilburg University, Tilburg, Netherlands, E-mail: nicola.jagers@uvt.nl 


\section{Introduction}

In 2008, the Special Representative to the Secretary-General on Business and Human Rights (SRSG) John Ruggie presented the Protect-Respect-Remedy Framework $^{1}$ which has triggered the development of a regulatory dynamic resulting in what Ruggie has called a 'business and human rights ecosystem'. ${ }^{2}$ The SRSG stressed the role of National Human Rights Institutions (NHRIs), noting that:

The actual and potential importance of these institutions cannot be overstated. Where NHRIs are able to address grievances involving companies, they can provide a means to hold business accountable. NHRIs are particularly well-positioned to provide processes - whether adjudicative or mediation-based - that are culturally appropriate, accessible, and expeditious. Even where they cannot themselves handle grievances, they can provide information and advice on other avenues of recourse to those seeking remedy. Through increased interchange of information, they could act as lynchpins within the wider system of grievance mechanisms, linking local, national and international levels across countries and regions. ${ }^{3}$

The idea that NHRIs have an important role to play in the quest to hold business accountable for human rights abuse, be it as advisors, mediators or adjudicators is increasingly being recognized. The 2011 UN Guiding Principles on Business and Human Rights (UNGPs) point out several roles that NHRIs can take on in the business and human rights domain such as 'helping States identify whether relevant laws are aligned with their human rights obligations and are being effectively enforced, and in providing guidance on human rights also to business enterprises and other non-State actors, ${ }^{4}$ and as an example of State-based

1 UN Doc A/HRC/8/5, Protect, Respect and Remedy: A Framework for Business and Human Rights: Report of the Special Representative of the Secretary-General on the Issue of Human Rights and Transnational Corporations and Other Business Enterprises, Human Rights Council (7 April 2008). 2 According to Ruggie this regulatory ecosystem differs from a hierarchical system. The regulatory dynamic that has evolved is 'one in which public and private governance systems - corporate as well as civil - each come to add distinct value, compensate for one another's weaknesses, and play mutually reinforcing roles - out of which a more comprehensive and effective global regime might evolve, including specific legal measures.' John Gerard Ruggie, 'Hierarchy of Ecosystem? Regulating Human Rights Risks of Multinational Enterprises' in César Rodriguez-Garavito (ed), Business and Human Rights: Beyond the End of the Beginning (Cambridge University Press 2017) 47.

3 UN Doc A/HRC/8/5 (2008) para 97.

4 Commentary to Principle 3, Guiding Principles on Business and Human Rights (UNGPs), United Nations, HR/PUB/11/04 (2011). <https://www.ohchr.org/Documents/Publications/ GuidingPrinciplesBusinessHR_EN.pdf > accessed 17 July 2020. 
grievance mechanisms. ${ }^{5}$ NHRIs themselves are increasingly claiming a role in this field ${ }^{6}$ and various international organizations have pointed out that NHRIs have a role to play. ${ }^{7}$

This development is also reflected in the ongoing process towards an international treaty on business and human rights (BHR-Treaty). This process, which started at the United Nations in $2014^{8}$, has culminated in a draft text, a zero-draft, in 2018. ${ }^{9}$ The text of an Optional Protocol to the BHR-Treaty was also released ${ }^{10}$ and contains an obligation for States Parties to establish a National Implementation Mechanism (NIM). ${ }^{11}$ The Optional Protocol has NHRIs in mind given the reference to the so-called Paris Principles, the Guidelines relating to the status of NHRIs. ${ }^{12}$ The Optional Protocol carves out a key role for such National Implementation

5 Commentary to Principle 25, UNGPS (2011).

6 See the Edinburgh Declaration, International Co-Coordinating Committee of National Human Rights Institutions for the Promotion and Protection of Human Rights (ICC) (10 October 2010) <https://www.ohchr.org/Documents/AboutUs/NHRI/Edinburgh_Declaration_en.pdf> accessed 17 July 2020. The Edinburgh Declaration is discussed in more detail infra.

7 See, inter alia, the Council of Europe's Committee of Ministers Recommendation CM/Rec(2016)3c to Member States on human rights and business, which stresses a role for NHRIs in developing National Action Plans (para 11), assist in offering due diligence training (para 28) and as a nonstate based judicial mechanism that can receive and adjudicate complaints (para 51) <https:// edoc.coe.int/en/fundamental-freedoms/7302-human-rights-and-business-recommendationcmrec20163-of-the-committee-of-ministers-to-member-states.html> accessed 17 July 2020.

8 UN Doc A/HRC/26/L 22/Rev 1, Elaboration of an international legally binding instrument on transnational corporations and other business enterprises with respect to human rights, Human Rights Council (25 June 2014), online <https://documents-dds-ny.un.org/doc/UNDOC/LTD/G14/ 064/48/PDF/G1406448.pdf?OpenElement> accessed 12 December 2019.

9 On 16 July 2019, the Open-Ended Intergovernmental Working Group on transnational corporations and other business enterprises (OEIGWG) released a revised draft text of the draft treaty text. This revised text was discussed during the intergovernmental negotiations at the firth session of the OEIGWG held from 14 to 18 October 2019. The second revised draft text was released in August 2020 and is available here online <https://www.ohchr.org/Documents/HRBodies/ HRCouncil/WGTransCorp/Session6/OEIGWG_Chair-Rapporteur_second_revised_draft_LBI_on_ TNCs_and_OBEs_with_respect_to_Human_Rights.pdf > accessed 30 August 2020.

10 Draft Optional Protocol to The Legally Binding Instrument to Regulate, in International Human Rights Law, the Activities of Transnational Corporations And Other Business Enterprises, OEIGWG, 2018: <https://www.ohchr.org/Documents/HRBodies/HRCouncil/WGTransCorp/ Session4/ZeroDraftOPLegally.PDF> accessed 17 July 2020. At the time of writing there has been no revision of this text presented by the OEIGWG. The references in this paper to the provisions in the Optional Protocol therefore refer to the 2018 first draft text of the Optional Protocol.

11 Article 1 Optional Protocol (2018).

12 Optional Protocol (2018) Article 2 asserts that States Parties shall consider the Principles Relating to the Status of National Institutions for the Protection and Promotion of Human Rights (Paris Principles) when designating or establishing the [NIM]. The Paris Principles are further discussed infra. 
Mechanisms to promote, monitor and implement the BHR-Treaty. With such an institutional arrangement, the future treaty would join the ranks of what has been called a new generation of human right treaties which call for the establishment of independent national bodies to connect a top down with a bottom up approach. ${ }^{13}$ Such institutional innovation dispersing and localizing authority aims to address the disconnect that exists in global human rights governance between international rules and domestic practice. As will be discussed in Section 6, similar institutional innovation can also be found in the governance design of the Optional Protocol to the Convention against Torture ${ }^{14}$ (OPCAT) and the Convention on the Rights of Persons with Disabilities ${ }^{15}$ (CRPD). These instruments mark a move from rule-making to rule implementation, formalizing relations among intermediaries, aimed at advancing global rules at the domestic level. ${ }^{16}$ The Optional Protocol reflects this emerging trend of localization of authority by envisioning a role for NHRIs in the governance structure of the future business and human rights treaty. As stated above, the call for a role for NHRIs in this field has become louder, yet, their role in human rights governance in general, and in the business and human rights domain in particular, is not yet well understood and undertheorized. ${ }^{17}$ The proposal for a national implementation mechanism in the Optional Protocol to the treaty on business and human rights offers an example of how the relationships between key governance actors are being rearticulated in the global human rights governance architecture in general. This paper critically examines the significance of NHRIs in the business and human rights domain.

NHRIs will first be introduced and examples of their current engagement with business and human rights will be provided. In particular, the prospects of these institutions to effectuate State compliance, promoting corporate respect of human rights and securing remedy for victims of business-related human rights abuse will be discussed. The paper identifies areas of common interest in the work of NHRIs on business and human rights and presents examples of concrete activities undertaken by NHRIs in this area to date. It will be shown how NHRIs are uniquely positioned to take up the issue of business and human rights but they face a

13 For an analysis of this development see Tom Pegram, 'Governing Relationships: The New Architecture in Global Human Rights Governance' (2015) 43:2 Millennium-J Int St, 618.

14 Optional Protocol to the Convention Against Torture, entered into force on 22 June 2006. On 12 February 2020, 90 States have ratified OPCAT.

15 Convention on the Rights of Persons with Disabilities, entered into force 3 May 2008. On 12 February 2020, 181 States have ratified CRPD.

16 See Pegram (n 14) discussing this shift with a focus on the institutional arrangements under OPCAT.

17 With the notable exception of the valuable work quoted in this article by Tom Pegram (n 14, 37, 44), Gauthier De Beco (n 134) and Linda Reif (n 30, 32). 
number of challenges. With a view to encouraging and facilitating more effective engagement by NHRIs, the paper reflects on opportunities for supporting and perhaps expanding the role of NHRIs in this field. From this perspective, it will be discussed whether the role foreseen in the Optional Protocol to the business and human rights treaty holds promise. (How) can NHRIs as intermediates contribute to closing governance gaps in the business and human rights field? It will be discussed how the evolution of the role of NHRIs in the business and human rights domain fits into what a broader development towards what has been called global experimentalist governance. ${ }^{18}$ Finally, with this analysis the article aims to add insight into NHRIs as a significant new class of formal organization in human rights governance.

\section{National Human Rights Institutions (NHRIs)}

To analyze the role of NHRIs ${ }^{19}$ in the business and human rights field, a better understanding of NHRIs is necessary. A NHRI is a 'body which is established by a Government under the Constitution, or by law or decree, the functions of which are specifically defined in terms of the promotion and protection of human rights' ${ }^{20}$ The idea of establishing national human rights institutions was first conceived in the aftermath of World War II. In 1946, the UN Economic and Social Council invited Member States to consider establishing information groups or local human rights committees. Subsequently, the UN General Assembly requested the SecretaryGeneral to submit a detailed report on NHRIs. In 1991, the first international workshop on National Institutions for the Promotion and Protection of Human Rights took place in Paris. A key outcome of this conference was the adoption by the UN General Assembly in 1993 of the Paris Principles relating to the status of national institutions (hereinafter: the Paris Principles), now broadly accepted as the international standard for NHRIs testing an institution's legitimacy and

18 Grainne de Búrca, Robert O Keohane and Charles Sabel, 'New Modes of Pluralist Global Governance' (2013) 45 Int'l L \& Politics, 723.

19 NHRIs can encompass a broad range of bodies that are mandated to promote and protect human rights at the national level. For the purpose of this paper, NHRIs are those bodies that are engaged with the accreditation-process at GANHRI (this process is further discussed infra).

20 UN Center for Human Rights, National Human Rights Institutions: A Handbook on the Establishment and Strengthening of National Institutions for the Promotion and Protection of Human Rights (1995) 39, <https://www.un.org/ruleoflaw/blog/document/national-humanrights-institutions-a-handbook-for-the-establishment-and-strengthening-of-nationalinstitutions-for-the-promotion-protection-of-human-rights/> accessed 17 July 2020. 
credibility. ${ }^{21}$ The Paris Principles lay down the requirements an entity must meet to show it has the capacity to be a NHRI. These requirements are quite general and focus on such things as the necessity of a broad mandate and independence. But there is no prescribed model for an NHRI and thus the diversity among NHRIs is great. Around the world six models can be discerned: human rights commissions; human rights ombudsman institutions; hybrid institutions; consultative and advisory bodies; institutes and centres and multiple institutions. ${ }^{22}$ The main types of NHRIs are national human rights commissions or institutes and national human rights Ombudsperson institutions. Mandates, resources and local context differ substantively. Given the vast diversity, the Paris Principles have formulated a rather generic description of what requirements a NHRI must meet, putting specific attention on formal independence, composition, mandate and competence of the institution. According to the Paris Principles, a NHRI must:

- be established by law;

- $\quad$ have a clearly specified role and a mandate that is as broad as possible;

- reflect pluralism in governing structures and independence of appointment procedures;

- have an infrastructure in accordance with its functions, with particular importance attached to the need for adequate funding;

- have the ability to perform a monitoring, advisory and recommendation function on various matters relating to human rights;

- relate to regional and international organizations;

- must promote public awareness, teaching and research on human rights;

- $\quad$ provide the possibility of handling individual complaints or petitions on human rights grounds. ${ }^{23}$

The United Nations Global Alliance of National Human Rights Institutions (GANHRI $^{24}$ is mandated to review and accredit NHRIs that are in compliance with the Paris Principles. ${ }^{25}$ This is done through a peer-review process undertaken by GANHRI's Sub-Committee on Accreditation (SCA). When compliant with the Paris

21 UN Doc A/RES/48/134, Principles relating to the Status of National Institutions (Paris Principles), UN General Assembly Res (1993), <https://www.un.org/documents/ga/res/48/a48r134.htm> accessed 10 December 2019.

22 According to the website of the United Nations Global Alliance of National Human Rights Institutions (GANHRI) <https://ganhri.org/nhri/> accessed 17 July 2020.

23 Paris Principles (1993).

24 Formally known as the International Coordinating Committee for National Institutions for the Promotion and Protection of Human Rights (ICC).

25 GANHRI interprets the Paris Principles in its General Observations: <https://nhri.ohchr.org/ EN/Pages/default.aspx> accessed 5 June 2020. 
Principles, the GANHRI can grant the institution $\mathrm{A}^{26}$ or $\mathrm{B}^{27}$ status. In general, GANHRI only accredits one institution per jurisdiction. ${ }^{28}$ Fully compliant NHRIs are granted the A-status which provides them with certain prerogatives. A-status NHRIs may make an oral statement under all substantive agenda items of the Human Rights Council; participate through video messages in the HRC plenary debates, including during the adoption of the outcome of the Universal Periodic Review of the country by the Council, the interactive dialogue following the presentation of a country mission report by a special procedures mandate holder and panels or annual discussions; submit documents, which will be issued with UN Document symbol; and take separate seating in all sessions. As pointed out by Reif, the accreditation-process of GANHRI that puts certain pressure on NHRIs and States to comply with the Paris Principles in order to be bestowed with certain (reputational) prerogatives, thus functions as a gatekeeper mechanism. ${ }^{29}$

In their interactions with the human rights' supervisory mechanisms, NHRIs form a bridge between the national and the international level. NHRIs are actively involved in the national reporting cycles and monitor follow up of international recommendations. In accordance with the Paris Principles, NHRIs shall promote and protect human rights at the national level. Human rights promotion is understood as to 'include those functions which seek to create a society where human rights are more broadly understood and respected. Such functions may include education, training, advising, public outreach and advocacy. ${ }^{30}$ Typically, NHRIs will be involved in advising government on legislation with a human rights dimension, monitoring compliance with international treaty obligations, pushing

26 As of 2019, 80 NHRIs were accredited as being fully compliant with the Paris Principles by GANHRI. Statistics available online: <https://nhri.ohchr.org/EN/AboutUs/GANHRIAccreditation/ Pages/default.aspx $>$ accessed 17 July 2020.

27 B-status is given to national institutions that are not fully compliant with the Paris Principles. As of 2019, GANHRI accredited 34 NHRIs with the B-status.

28 There are a few exceptions. For example, in Europe some countries have more than one accredited institution. These countries are Bulgaria, Switzerland and the United Kingdom. Besides the institutions accredited by GANHRI, a country may have multiple national organizations dealing with human rights issues. These organizations may a have a narrower mandate such as, for example, equality bodies. In this article the focus is on NHRIs as accredited by GANHRI.

29 Linda C Reif, 'The UN Guiding Principles on Business and Human Rights and Networked Governance: Improving the Role of Human Rights Ombudsman Institutions as National Remedies' (2017) 17 Human Rights Law Review 603, 614-615.

30 ICC Sub-Committee on Accreditation (ICC-SCA) General Observations 1.2 (May 2013) <https:// nhri.ohchr.org/EN/AboutUs/Governance/Documents/ICC\%20SCA\%20General\%20Observations. pdf $>$ accessed 17 July 2020. See also, UN Office of the High Commissioner for Human Rights (OHCHR) National Human Rights Institutions: History, Principles, Roles and Responsibilities (2010) 55 <www.ohchr.org/Documents/Publications/PTS-4Rev1-NHRI_en.pdf> accessed 10 July 2019. 
for the ratification of human rights treaties and protocols, human rights education and overall monitoring of the human rights situation in the country. ${ }^{31}$ The protection functions of NHRIs 'may be understood as those that address and seek to prevent actual human rights violations. Such functions include monitoring, inquiring, investigating and reporting on human rights violations, and may include individual complaint-handling, ${ }^{32}$ The Paris Principles do not require NHRIs to have a complaints-handling function yet some NHRIs do have the mandate that allows individual dispute resolution. Even though it is not required, it has been recommended that NHRIs may handle complaints submitted to them by a complainant and by settling the case through conciliation and mediation, thereby relieving the existing case-load of courts; ensuring victims of human rights violations receive compensation, including encouragement of the establishment of the fund for this purpose; assisting victims seeking redress with information on the law and the legal system' as well as seeking 'informal legal redress mechanisms through conciliation or through binding decisions. ${ }^{33}$ Finally, the importance is stressed of 'regular and constructive engagement with all relevant stakeholders', through 'working relationships, as appropriate, with other domestic institutions established for the promotion and protection of human rights, including subnational statutory human rights institutions, thematic institutions, as well as civil society and non-governmental organizations. ${ }^{34}$

In 1990, there were only eight institutions that could be considered as official NHRIs. The fact that there are now 114 accredited NHRIs ${ }^{35}$ (of which 80 have been found to be fully compliant with the Paris Principles and thus accredited with A-status) reflects the proliferation of these institutions in recent years. ${ }^{36}$ Besides

31 For more on the functions of NHRIs see: Linda Reif, 'The Shifting Boundaries of NHRI Definition in the International System' in Ryan Goodman and Thomas Pegram (eds), Human Rights, State Compliance, and Social Change (Cambridge University Press 2012) 52.

32 ICC-SCA, General Observation 1.2 (2013).

33 Article 33 (a) Nairobi Declaration (2008), adopted by the Ninth International Conference of National Institutions for the Promotion and Protection of Human Rights: <https://www.ohchr.org/ Documents/Countries/NairobiDeclarationEn.pdf> accessed 17 July 2020. See also ICC-SCA General Observations 1.10 (2013).

34 GANHRI-SCA, General Observations 1.5 (21 February 2018): <https://nhri.ohchr.org/EN/ AboutUs/GANHRIAccreditation/General\%200bservations\%201/EN_GeneralObservations_

Revisions_adopted_21.02.2018_vf.pdf > accessed 17 July 2020.

35 See $n 27$.

36 For an analysis of the spread across the world of NHRIs see: Thomas Pegram, 'Diffusion Across Political Systems: The Global Spread of National Human Rights Institutions’ (2010) 32:3 Human Rights $Q$ 729. As Pegram shows, the spread of NHRIs across the globe has gone beyond liberal democratic jurisdictions to include political systems that cannot be considered consolidated democracies. 
the cooperation in GANHRI at the global level, NHRIs have also devised networks for collaboration at the regional level. In Europe, NHRIs collaborate in the European Network of National Human Rights Institutes (ENNHRI). ${ }^{37}$ In Africa, transnational collaboration takes place in the Network of African National Human Rights Institutions (NANHRI) created in $2007 .{ }^{38}$ In the Asia-Pacific region, an alternative peer review mechanism has developed known as the Asia Pacific Forum established in 2006. ${ }^{39}$ This forum administers its own evaluation of prospective and current members according to the Paris Principles. In the Americas, NHRIs collaborate in the Network of National Institutions of Human Rights of the American Continent. ${ }^{40}$ In addition to the regional networks, NHRIs also collaborate in several cross-regional forums. ${ }^{41}$

The Paris Principles ${ }^{42}$ as a framework and the collaboration between NHRIs reflects what Pegram has defined as 'regulatory stewardship'; the governance structure is designed of mutual-monitoring and support responsibilities among intermediaries themselves. ${ }^{43}$ As will be further discussed in Section 7, such a networked governance ${ }^{44}$ design helps to protect the independence of NHRIs which is crucial for the effective functioning of these entities.

\section{Emerging Recognition of NHRIs in the Business and Human Rights Field}

Traditionally, NHRIs have focused on the State and its compliance with human rights. In recent years, we see NHRIs increasingly using their mandate to address human

37 ENNHRI <www.ennhri.org> accessed 17 July 2020. Currently 43 NHRIs across wider Europe are a member of ENNHRI.

38 NANHRI < www.nanhri.org > accessed 17 July 2020. Currently 44 African NHRIs are a member on NANHRI.

39 Asia Pacific Forum <www.asiapacificforum.net> last accessed 17 July 2020. Currently, 25 NHRIs are member of this network.

40 Fourteen NHRIs cooperate within this network but at the time of writing the degree of cooperation is unclear. The Network does not have a website. In July 2018, the Extraordinary Assembly of the Network approved the statutes of a new and permanent secretariat to be based in Panama. 41 For example, the Commonwealth Forum of National Human Rights Institutions, comprised of former and current members of the British Commonwealth, such as Canada and Australia. NHRIs also participate in the Arab-European Human Rights Dialogue which includes seven NHRIs from the Arab countries and seven from European countries.

42 And the ICC/GANHRI's General Observations which interpret the Paris Principles.

43 Tom Pegram, 'Regulatory Stewardship and Intermediation: Lessons from Human Rights Governance' (2017) Annals Aapss 670.

44 For more on NHRIs and networked governance, see Reif (n 30) 613. 
rights abuse by private actors. ${ }^{45}$ At the time when the Paris Principles were adopted, there was less attention for the impact of corporations on human rights than is the case nowadays. The traditional State-centric focus of international human rights law may provide an explanation for the fact that the Paris Principles do not explicitly mention the need for NHRIs to engage with non-State actors. ${ }^{46}$ Nevertheless, it is argued that the Paris Principles do provide sufficient space for NHRIs to take up a critical role in preventing and responding to human rights violations committed by corporations. Brodie distinguishes four specific ways in which the Paris Principles can be read as encouraging NHRI engagement with business and human rights. ${ }^{47}$ In general, the Paris Principles state that NHRIs must be vested with competence to promote and protect human rights and be given as broad a mandate as possible. The Paris Principles do not limit this to State actors. Secondly, under 'methods of operation', the Paris Principles state that NHRI may engage with non-state actors by providing that an NHRI shall 'freely consider any information and any documents necessary for assessing situations falling within its competence' ${ }^{48}$ Furthermore, the Paris Principles require institutions to 'maintain consultations with other bodies, whether jurisdictional or otherwise, responsible for the promotion and protection of human rights' ${ }^{49}$ Moreover, in the General Observations which provide interpretations of the Paris Principles, it is stated that:

an NHRI's mandate should be interpreted in a broad, liberal and purposive manner to promote a progressive definition of human rights which includes all rights set out in international, regional and domestic instruments, including economic, social and cultural rights.

45 On the role of NHRIs in implementing the UNGPs see generally: Veronika Haasz, 'The Role of National Human Rights Institutions in the Implementation of the UN Guiding Principles' (2013) 14 Human Rights Review 165; Meg Brodie, 'Pushing the Boundaries: The Role of National Human Rights Institutions in Operationalising the "Protect, Respect, Remedy" Framework' in Radu Mares (ed), The UN Guiding Principles on Business and Human Rights: Foundations and Implementation (Martin Nijhoff Publishers 2012) 245; and Reif (n 30).

46 Surya Deva, 'Corporate Human Rights Abuses: What role for National Human Rights Institutions', in Hitoshi Nasu and Ben Saul (eds), Human Rights in the Asia-Pacific region: Towards Institution Building (Routledge 2011) 241.

47 Meg Brodie, 'Pushing the Boundaries: The Role of National Human Rights Institutions in Operationalising the 'Protect, Respect and Remedy' Framework' in Radu Mares (ed), The UN Guiding Principles on Business and Human Rights. Foundations and Implementation (Martin Nijhoff Publishers 2012) 245, 250-251.

48 Paris Principles, methods of operation, Article (a), (b) (emphasis added).

49 Paris Principles, methods of operation, Article (f) and under (g), NHRIs shall 'develop relations with the non-governmental organizations devoted to promoting and protecting human rights. 
Specifically, the mandate should: extend to the acts and omissions of both the public and private sectors. $^{50}$

This provides NHRIs with the mandate to engage with national, regional and international bodies that work on business and human rights such as the OECD and its National Contact Points or the UN Working Group on Business and Human Rights. Fourthly, Brodie points out that the requirement that a NHRI must consult with various representative groups can be read as to include also the private sector. ${ }^{51}$ Thus, Brodie concludes that such a reading of the Paris Principles provides that legislation establishing an NHRI should enable engagement with corporations or at the very least not exclude such engagement. ${ }^{52}$ Recently, NHRIs have actively started to utilize the room the Paris Principles allow to engage with the issue of business and human rights. The next section will provide some illustrations of such activities.

Collaborative networks of NHRIs have confirmed that NHRIs have a role to play in addressing business and human rights issues. ${ }^{53}$ In 2009, the global network of NHRIs, GANHRI (then called the International Coordinating Committee, ICC), established a Working Group on Business and Human Rights, the first ICC's thematic Working Group. In 2010, the ICC's 10th Biennial Conference held in Scotland was dedicated to the topic of business and human rights. Over 80 NHRIs adopted the Edinburgh Declaration. ${ }^{54}$ This declaration affirms the mandate, identifies the role and indicates the functions of NHRIs on business and human rights across the

50 General Observation 1.2 Human Rights Mandate, 21 February 2018, 7. General Observation 2.9 moreover suggests that, depending on the mandate the 'powers and functions [of a NHRI] might include: the ability to receive complaints against both public and private bodies in its jurisdiction'. 51 Paris Principles, composition, Article 1 (a), Brody (n 48) 251.

52 Brodie (n 48) 252.

53 Various meetings have been held exploring the role of NHRI and business and human rights most notably in relation to access to effective remedy. See, inter alia, the 2015 Conference on Legal Accountability of Business for Human Rights Impacts: <https://nhri.ohchr.org/EN/Themes/ BusinessHR/Business\%20Womens\%20and\%20Childrens\%20Rights/Report_NHRI\%20dialogue \%20on\%20BandHR_2015_03_14-15.pdf> (accessed 17 July 2020) the 2016 Rabat Workshop on Guaranteeing access to remedies for business-related human rights abuses: Role of NHRIs; the 2018 Chatham House Dialogue on Access to Remedies in Business and Human Rights: The Role of National Human Rights Institutions: < https://chathamhouse.soutron.net/Portal/Default/en-GB/ RecordView/Index/179194> accessed 17 July 2020; and the cases studies and workshop report Remedy in Business and Human Rights Cases The Role of National Human Rights Institutions. Deutsches Institute für Menschenrechte and the Danish Insitute for Human Rights (April 2018) (hereinafter: 'Berlin Report'): <https://www.humanrights.dk/sites/humanrights.dk/files/media/ dokumenter/udgivelser/hrb_2019/nhri_conference_report_and_case_studies_2019.pdf> accessed 12 February 2020.

54 Edinburgh Declaration (2010). 
three pillars of the UN Protect, Respect and Remedy Framework. The Edinburgh Declaration emphasized 'the important role national human rights institutions can play in addressing corporate-related human rights challenges, both as a body at the international level, at the regional level and individually at the national level'. ${ }^{55}$ The Declaration provides a number of examples of activities NHRIs could take up, such as: engaging with governments to promote greater awareness of the impact of business enterprises on the realization of human rights ${ }^{56}$ and advocating and advising government to introduce national legislation ${ }^{57}$; provide guidance to business on how to integrate human rights into their daily business ${ }^{58}$; research business impact on human rights ${ }^{59}$; facilitate dialogue between corporations, government and civil society ${ }^{60}$; document violations and examine conditions of access to justice ${ }^{61}$. The Edinburg Declaration also calls on NHRIs with complaint handling functions to consider utilizing these to address business and human rights issues and for NHRIs to mediate between corporations, governments, trade unions and victims. ${ }^{62}$

Regional collaborative networks have also recognized the role NHRIs can play in the field of human rights and business. On the African continent, NHRIs cooperating in NANHRI adopted the 2011 Yaoundé Plan of Action affirming their collective commitment to strengthen their capacity on business and human rights, address business-related human rights abuses, highlighting three specific areas: labour, environment and land related human rights abuses. ${ }^{63}$ In Europe, the NHRIs collaborate in ENNHRI, the European Network of National Human Rights Institutions. ${ }^{64}$ One of its four working groups engages with business and human

55 Para 11, Edinburgh Declaration (2010).

56 A II Edinburgh Declaration (2010).

57 A III Edinburgh Declaration (2010).

58 A IV Edinburgh Declaration (2010).

59 A V Edinburgh Declaration (2010).

60 A VIII Edinburgh Declaration (2010).

61 B I \& II Edinburgh Declaration (2010).

62 C \& D Edinburgh Declaration (2010).

63 Yaoundé Plan of Action on Business and Human Rights and Report on the Business and Human Rights in 29 September - 01 October 2011, online: https://www.nanhri.org/our-work/ thematic-areas/business-human-rights/ accessed 17 July 2020. In its strategic plan 2012-2014, NANHRI identified business and human rights as one of its strategic priority areas and NANHRI's Biennial conference in October 2013 in Accra, Ghana focused on business and human rights. For more information on NANHRI's activities in the field of business and human rights see online: <https://www.nanhri.org/our-work/thematic-areas/business-human-rights/> accessed 17 July 2020.

$64<$ www.ennhri.org> accessed 17 July 2020. 
rights. ${ }^{65}$ In the Americas, in 2011, the NHRI-Network organized a regional seminar on business and human rights, resulting in a declaration and action plan.

Besides NHRI claiming a role for themselves, international organizations have also increasingly started to acknowledge NHRIs as important actors in the field. When the Human Rights Council adopted the UNGPs, the Council welcomed 'the important role of [NHRIs] established in accordance with the Paris Principles in relation to business and human rights, and encourages [NHRIs] to develop further their capacity to fulfil that role effectively'. ${ }^{66}$ The role envisioned in most documents concerns mainly the promotional tasks of NHRIs such as providing information and advice to government, corporations and civil society. But increasingly, expectations are also expressed regarding the functions of NHRIs in protecting human rights by facilitating access to remedy. As the above mentioned quote by the SRSG Ruggie makes clear, NHRIs are seen as particularly adept at facilitating access to remedy by acting 'as lynchpins within the wider system of grievance mechanisms'. ${ }^{67}$ The UN Working Group on Business and Human Rights has started a project to analyze the role of NHRIs in facilitating access to remedy for businessrelated human rights abuses. ${ }^{68}$

The growing expectations regarding a role for NHRIs in the field of business and human rights, NHRIs have culminated in the Optional Protocol to the future BHR treaty which envisions a role for national implementation mechanisms to promote compliance, monitor and implement the future treaty. What this role would imply exactly will be further discussed in Section 5.

In sum, a development can be discerned where there is an increasing expectation that NHRIs have a significant role to play in addressing business and human rights issues. NHRIs have gradually seized the room that the Paris Principles allow

65 In 2012, European Group of National Human Rights Institutions adopted The Berlin Action Plan on Business and Human Rights <https://www.business-humanrights.org/en/european-group-ofnational-human-rights-institutions-develops-action-plan-on-business-human-rights> accessed 17 July 2020.

66 UN Doc HRC Res 17/4 (2011), para 10.

67 UN Doc A/HRC/8/5 (2008), para 97.

68 This follows a request by the Human Rights Council in July 2018, See UN Doc A/HRC/38/L 18. A two-day global consultation was convened in the Fall on 2019 on these issues, and the Council has been requested to be informed by its 44th session. This project complements research conducted by the OHCHR on Accountability and Remedy that also looked into the role of NHRIs: <https:// www.ohchr.org/EN/Issues/Business/Pages/OHCHRaccountabilityandremedyproject.aspx> accessed 17 July 2020. 
for these entities to take up such a role. In the next section, some examples of NHRI engagement will be discussed.

\section{NHRIs and Business and Human Rights: Current Practice and Challenges}

The previous section has demonstrated how NHRIs are increasingly are being referred to as actors of growing significance in the business and human rights domain, a role NHRIs are gradually starting to acknowledge and take up themselves. But only NHRIs with jurisdiction over both public and private actors and broad promotion and protection powers are able to engage with business and human rights matters in practice. This section provides an overview of some of the activities that NHRIs have started to deploy in this field, independently and/or in collaboration with others. This is by no means an exhaustive overview but rather serves to illustrate some of the current involvement of NHRIs which brings to light several challenges facing NHRIs involvement in this field. ${ }^{69}$ NHRIs differ vastly when it comes to their mandates, resources and capacities and as a result their activities in the field of business and human rights also differ considerably. It is thus not possible to speak of the role for NHRIs in the business and human rights domain. The diverse landscape makes is hard to compare or present a comprehensive overview. Yet, by discussing some of the recent activities of various NHRIs, it is possible to draw some conclusions about the common challenges NHRIs face when engaging with business and human rights.

At the national level, NHRIs are increasingly picking up a role in the BHR domain across the three pillars of the 'Protect, Respect and Remedy' framework.

(i) State duty to protect

69 Here only a small section of the business and human rights engagement is presented. For more examples and best practices see, inter alia: Claire Methven O’Brien, Cathrine Poulsen Hansen, Sofia Manukyan and Deniz Utlu, 'NHRI actions in the field of business and human rights: Update on steps to implement the 2010 Edinburgh Declaration' <https://www.ohchr.org/Documents/ Issues/Business/NationalPlans/ClaireMethvenOBrien_EdinburghDeclaration.pdf $>$ accessed 17 July 2020; Haász (n 46); Annex I of the policy report The role of non-EU national human rights institutions in the implementation of the UN Guiding Principles on Business and Human Rights, with a focus on Eastern Partnership Countries (October 2012) Directorate- General for External Policies of the Union, EXPO/B/DROI/2012/08. 
According to principle 1 of the UNGPs:

States must protect against human rights abuse within their territory and/or jurisdiction by third parties, including business enterprises. This requires taking appropriate steps to prevent, investigate, punish and redress such abuse through effective policies, legislation, regulations and adjudication. ${ }^{70}$

Furthermore, 'States should set out clearly the expectation that all business enterprises domiciled in their territory and/or jurisdiction respect human rights throughout their operations. ${ }^{71}$ And Principle 3 explains how States should operationalize their obligation to protect by enforcing laws; making sure that other laws and policies do not constrain but enable business respect for human rights; provide effective guidance to business enterprises on how to respect human rights and encourage, business enterprises to communicate how they address their human rights impacts. ${ }^{72}$ The Commentary to Principle 3 states that NHRIs that are compliant with the Paris Principles 'have an important role to play in helping States identify whether relevant laws are aligned with their human rights obligations and are being effectively enforced, and in providing guidance on human rights also to business enterprises and other non-State actors'. ${ }^{73}$

Several NHRIs have taken up a role in monitoring the State obligation to protect against corporate human rights abuse. NHRIs have been involved, to different degrees, in the creation of National Action Plans on Business and Human Rights (NAPs). The European Union called on its members to adopt national action plans laying out how they would implement the UNGPs. ${ }^{74}$ The development of NAPs on Business and Human Rights has been pushed by civil society organizations ${ }^{75}$ and is

70 Principle 1, UNGPs (2011).

71 Principle 2, UNGPs (2011).

72 Principle 3, UNGPs (2011).

73 Commentary to Principle 3, UNGPs (2011).

74 EU Council, EU Strategic Framework and Action Plan on Human Rights and Democracy (2012) at 25 $<$ https://europa.eu/capacity4dev/disability-and-development-network/document/eu-strategic-

framework-and-action-plan-human-rights-and-democracy-1> accessed 17 July 2020. The UK was the first to adopt such a plan.

75 See, for example, the National Action Plans Toolkit developed by the Danish Institute for Human Rights (DIHR) together with the International Corporate Accountability Roundtable (ICAR) meant to inform the various stakeholders involved in the NAP process. The version 2017 is available online: <https://static1.squarespace.com/static/583f3fca725e25fcd45aa446/t/ 5a3bd3bf9140b7ab3607ee6d/1513870272126/FINAL+NAPs+Toolkit+Update+2017.pdf> accessed 17 July 2020. 
also found strong support with the UN Working Group on Business and Human Rights. ${ }^{76}$ In 2014, the Human Rights Council encouraged all UN Member States to adopt NAPs. ${ }^{77}$ Also at the regional level, States have been called upon to adopt national action plans on business and human rights. ${ }^{78}$ At the time of writing, 23 countries across the world have adopted a NAP and 14 countries are in the process of doing so. ${ }^{79}$ The UN Working Group on Business and Human Rights has recommended that NHRIs are invited to contribute to the process of creating a NAP and should also be involved in the monitoring thereof. ${ }^{80}$ In several countries, NHRIs have indeed played an active role, to different degrees, in the NAP process. For example, the NHRIs of Germany and Zambia undertook a national base-line assessment in preparation of the NAP. NHRIs in countries such as the Netherlands, Scotland, Kenya and North Ireland have been involved in different ways in the development of NAPs. Many NAPs make direct reference to NHRIs, some highlighting specific roles. For example, the NAP of Chile, commits the Chilean NHRI to train staff, update material, and introduce the UNGPs into the recommendations they make to the State. ${ }^{81}$ Notably, Italy's NAP mandates that the State establish an NHRI. ${ }^{82}$

Besides a role in the creation of National Action Plans on Business and Human Rights, various NHRIs have advanced specific proposals for legal reform to

76 The UN Working Group on the issue of human rights and transnational corporations and other business enterprises (also referred to as the Working Group on Business and Human Rights) was established by the Human Rights Council in 2011 (resolution 17/4) to promote the effective dissemination of the UNGPs. The Working Group has developed guidance to assist all stakeholders involved in NAP processes. The guidance in available online: <https://www.ohchr.org/ Documents/Issues/Business/UNWG_NAPGuidance.pdf> accessed 12 February 2020.

77 UN Doc HRC Res 26/22, Human Rights and Transnational Corporations and Other Business Enterprises, 27 June 2014, A/HRC/26.L.1.

78 The Organisation of American States (OAS) called for the adoption of NAPs in 2016, AG/RES 2887 (XLVI-O/16) PROMOTION AND PROTECTION OF HUMAN RIGHTS1/2/3/4/5/6/ June 14; The Council of Europe also recommended that its Member States adopt a NAP on business and human rights (2016) COE Committee of Ministers, Recommendation on Business and Human Rights, 11.

79 The countries that have adopted a NAP are: Belgium; Chile; Colombia; Czech Republic; Denmark; Finland; France; Georgia; Germany; Ireland; Italy; Lithuania; Luxembourg; Netherlands; Norway; Poland; Slovenia; South Korea; Spain; Sweden; Switzerland; United Kingdom; and the United States. All NAPs on business and human rights are available online $<$ www.globalnaps.org > accessed on 12 February 2020.

80 UN Working Group on Business and Human Rights (2015) Guidance version 2.0, 5-7, 9-10. This is also recommended by the Council of Europe in its 2016 Recommendation, para 11.

81 See para 1.7 of the Chilean NAP <https://globalnaps.org/country/chile/> accessed 12 February 2020.

82 See 10 of the Italian National Action Plan on Business and Human Rights 2016-2021 <https:// mk0globalnapshvllfq4.kinstacdn.com/wp-content/uploads/2017/10/NAP-Italy.pdf > accessed 17 July 2020. 
promote the implementation of the UNGPs at the national level. ${ }^{83}$ For example, NHRIs have been engaged, with the nascent trend towards the adoption of national laws mandating human rights due diligence. ${ }^{84}$ Several NHRIs have conducted research in specific areas which have led to evidence-based recommendations for adjusting laws. ${ }^{85}$

Moreover, an increasing number of NHRIs are addressing the duties of States regarding business and human rights in their interactions with international and regional human rights bodies. For example, The Canadian and Danish NHRI have included relevant recommendations in the second round of the Universal Periodic Review. The European network of NHRIs has taken a position on the BHR-treaty calling on States to actively contribute to the negotiations. ${ }^{86}$

(ii) Corporate responsibility to respect.

According to Principle 11 of the UNGPs: 'Business enterprises should respect human rights. This means that they should avoid infringing on the human rights of others and should address adverse human rights impacts with which they are involved. ${ }^{87}$ The UNGPs explain which processes and policies companies must have in place to act with due diligence and meet their responsibility to respect. NHRIs are only briefly mentioned in the commentary to Principle 23 which addresses the responsibility of corporations when operating in conflict-affected areas. The commentary provides that 'in complex contexts such as these, business enterprises should ensure that they do not exacerbate the situation. In assessing how best to respond, they will often be well advised to also [...] consult externally with credible, independent experts, including from Governments, civil society, national human rights institutions and relevant multi-stakeholder initiatives. ${ }^{88}$ NHRIs have started to play a role in the second pillar of the Framework by providing expertise and advise to business and human rights issues. Notably, the

83 The NHRIs of Kenya, India and Cambodia have put forward suggestions to amend national laws to improve access to justice for those that have experienced harm as a result of corporate conduct. 84 Since France adopted a Duty of Vigilance Law in 2017, several countries have followed with similar laws requiring companies to undertake human rights. An example is the child labor due diligence legislation adopted in the Netherlands in 2019. For more information on this emerging development, see <https://www.business-humanrights.org/en/mandatory-due-diligence> accessed 17 July 2020.

85 To name an example: the Australian NHRI has conducted research into age discrimination in the workplace.

86 See the ENNHRI statement <http://www.ennhri.org/IMG/pdf/ennhri_statement_on_zero_ draft.pdf $>$ accessed 17 July 2020.

87 Principle 11, UNGPS (2011).

88 Commentary to Principle 23, UNGPS (2011). 
Danish Human Rights Institute has taken on an active role in advising companies on the corporate responsibility to respect. ${ }^{89}$ Other NHRIs have also developed guidance for business on human rights. ${ }^{90}$ Often, these activities such as promoting ways to combat discrimination in hiring and employment termination or covering other labor issues are not labelled as 'business and human rights' matters which is often associated more with addressing transnational corporate activity. However, these promotional activities must also be considered as belonging to the business and human rights domain. ${ }^{91}$

(iii) Access to remedy

The third pillar of the Protect, Respect, Remedy Framework addressed access to remedy:

As part of their duty to protect against business-related human rights abuse, States must take appropriate steps to ensure, through judicial, administrative, legislative or other appropriate means, that when such abuses occur within their territory and/or jurisdiction those affected have access to effective remedy. ${ }^{92}$

It is especially in the field of providing access to remedy for victims of corporate related human rights abuse where high expectations for a role for NHRIs are held. In fact, the UNGPs envision NHRIs as State-based, non-judicial grievance mechanisms which can provide effective and accessible remedies for business-related human rights abuse. According to Principle 27, States should provide effective and appropriate non-judicial grievance mechanisms and the Commentary to this Principle stipulates that NHRIs 'have a particularly important role to play' as Statebased non-judicial grievance mechanism. ${ }^{93}$

89 See <https://humanrights.dk/our-work/business/working-companies> accessed 17 July 2020.

90 See, for example, the guidance in the area of employment developed by the UK Equality and Human Rights Commission <https://equalityhumanrights.com/en/advice-and-guidance?who=organisation> accessed 17 July 2020. The Netherlands NHRI has conducted research concerning pregnancydiscrimination, age-discrimination in hiring practices and equal-pay. This has resulted in policy advise to government and corporations: www.mensenrechten.nl (in Dutch; accessed 17 July 2020). Other NHRIs that have been involved in training and awareness-raising are the NHRIs of Kenya and Australia.

91 See also Reif (n 30) 630.

92 Principle 25, UNGPs (2011).

93 Commentary to Principle 27, UNGPs (2011). 
Access to remedy can be considered in a narrow and in a broader sense. ${ }^{94}$ In a narrow sense, access to remedy concerns adjudicating individual or collective disputes. As mentioned previously, the Paris Principles do not require NHRIs to have a complaint handling mandate but where NHRIs do have such a mandate it is argued that these NHRIs can contribute to improve access to remedy in cases of adverse human right effect caused by business activity. Some NHRIs have a mandate for adjudicative dispute resolution regarding human rights in general or with regard to certain categories, for example, employment discrimination or labour disputes. ${ }^{95}$ In such cases, NHRI may issue binding decisions or non-binding recommendations. NHRIs sometimes have the mandate to act as mediators or conciliators, in other words these NHRIs can play a role in agreement-based dispute resolution. ${ }^{96}$ Many NHRIs, however, do not have the mandate to directly address individual complaints of corporate abuse. ${ }^{97}$

Nevertheless, many NHRIs play a role in access to remedy if this is perceived in a broader sense as facilitating such access by supporting victims, providing

94 For an illustration of the various ways in which NHRIs are involved in access to remedy in business and human rights issues, see the report of the NHRI workshop held in Berlin in 2018: Case studies and workshop report, Remedy in Business and Human Rights. Cases. The Role of NHRIs (April 2019), Deutsches Institute für Mensenrechte, the Danish Institute for Human Rights (Berlin report, 2019) <https:/www.humanrights.dk/sites/humanrights.dk/files/media/dokumenter/ udgivelser/hrb_2019/nhri_conference_report_and_case_studies_2019.pdf $>$ accessed 12 February 2020.

95 In a report by the Danish Institute for Human Rights (DIHR) the role of NHRIs in access to remedy in business and human rights is analyzed based on a survey among NHRIs. An interesting observation is that the NHRIs in Africa, the Americas and Asia-Pacific all have complaintshandling mandates. In Europe, half of the NHRIs that responded to the questionnaire do not have a mandate to handle complaints related to business and human rights. DIHR, National Human Rights Institutions and Access to Remedy in Business and Human Rights, 25 March 2020, 14 $<$ https://www.humanrights.dk/publications/national-human-rights-institutions-access-

remedy-business-human-rights> (accessed 17 July 2020). An overview of the role European NHRIs play in dispute resolution, see the study by Lorna McGregor, Rachel Murray, Shirley Shipman and Helene Tyrrell, National Human Rights Institutions in Europe and Dispute Resolution: A Mapping (April 2017) <https://www1.essex.ac.uk/hrc/documents/50647_NHRI_ Mapping_Report_web.pdf > accessed 17 July 2020).

96 A mediation or conciliation role rather than an adversarial one is more common for NHRIs. For examples see Section 3.3. DIHR (2020).

97 There is little comprehensive research on this but for Europe, see McGregor, Murray, Shipman and Tyrell (n 97). See also 'Improving accountability and access to remedy for victims of businessrelated human rights abuse through State-based non-judicial mechanisms', UN Doc A/HRC/38/20 (14 May 2018) <https://documents-dds-ny.un.org/doc/UNDOC/GEN/G18/132/70/PDF/G1813270. pdf?OpenElement> accessed 20 July 2019. For a more global perspective on how NHRIs use their mandate to facilitate access to an effective remedy in the context of business and human rights, see the report by DIHR (2020). 
information and advice on which remedy-avenues are available or by using their investigatory powers to identify obstacles for victims and suggest improvements in national legislation to improve access to remedy. In recent years, several NHRIs have used their mandate to conduct inquiries to investigate specific situations of human rights abuse and remedy-related issues. For example, in 2018, the Australian NHRI announced a national inquiry into sexual harassment in Australian workplaces. ${ }^{98}$ In 2016, Kenya's National Commission on Human Rights has conducted a public inquiring into certain mining activities. Based on these experiences, the Commission reached the conclusion that the public inquiry's is a successful instrument to provide remedy to victims of business-related human rights abuses as it brings together multiple duty-bearers and rights-holders. ${ }^{99}$ The Portuguese NHRI, which is the Ombudsman, has the mandate to investigate. Moreover, the Ombudsman is entitled to compel evidence as well as testimony, conduct inspection visits without prior notice and request actions within the investigation. ${ }^{100}$ An example of a creative interpretation of the mandate of a NHRI is the ongoing investigation by the Commission on Human Rights of the Republic of the Philippines. The Commission has held public hearings in various places around the world on the potential liability of major fossil fuel companies for climate change-related impacts on human rights in the Philippines. ${ }^{101}$

In sum, as mentioned previously, in the UNGPs, the potential of NHRIs in the field of business and human rights is stressed. This expectation has resonated in multiple policy documents and been repeated by many scholars. NHRIs are frequently referred to as promising actors in the business and human rights domain. As the examples above show, NHRIs are indeed involved in many ways ranging from the promotion of human rights towards States and corporations and also in protecting human rights by facilitating access to remedy in a narrow and in a broader sense. NHRIs have started to take up these functions across the three pillars of the Protect-Respect, Remedy Framework. Nevertheless, the engagement with business and human rights matters remains quite limited in light of the mounting expectations. The next section will address some of the challenges NHRIs face when engaging with business and human rights.

98 The national inquiry process does not deal with individual complaints but rather aims to address systemic issues and aims to provide recommendations for broader change and remedial action. See, Berlin report (n 54) 8-9.

99 Berlin report (n 54) 17-18.

100 Example provided in DIHR (2020) 19.

101 Commission on Human Rights of the Republic of the Philippines (2018), 'PHL at the forefront of seeking climate justice with CHR's landmark inquiry on the effects of climate change to human rights'<http://chr.gov.ph/nicc-2/> accessed 10 July 2019. 


\subsection{Challenges}

Admittedly, the above section provides a rather sketchy overview of ongoing activities of the various NHRIs in the field of business and human rights. As stated, NHRIs differ vastly in their modus operandi precluding a comprehensive overview and complicate comparison among NHRIs. Yet, some general conclusions regarding the challenges NHRIs face can be drawn. In theory, NHRIs are uniquely positioned to address the impact of business on human rights. NHRIs are 'inbetweens' bridging the international human rights governance and the domestic level. Their status as independent entities enables these entities to take up this role functioning apart but alongside government, civil society and corporations. This position of NHRIs in general can bring along tensions which will also be there in the field of business and human rights. Corporations can be both potential allies and human rights abusers that should be held to account. ${ }^{102}$ This balancing act is not new for NHRIs which are used to taking on the role of advisor and monitoring body for the government simultaneously.

From the emerging practice of NHRI engagement with the business and human rights agenda, several challenges have become apparent. Three challenges will be addressed here. Firstly, there is the challenge of a practical nature that NHRIs encounter. A second challenge concerns the restrictions some NHRIs face when addressing the private sector. And, thirdly, NHRIs mostly have national mandates which may pose obstacles when confronted with the transnational character of corporate activities.

The practical challenges NHRIs face when becoming engaged with business and human rights are multiple. ${ }^{103}$ These challenges concern lack of resources, capacity, knowledge of corporate activities and functioning and overall low level of human rights compliance in a country. The tasks in the business and human rights domain are vast, involving potentially a huge number of actors to target, which operate across national borders. In accordance with the Paris Principles, the mandate of NHRIs must be as broad as possible, monitoring State compliance with all human rights. Adding non-State actors to the mix requires NHRIs to venture out into relatively unchartered territory and may result in a burgeoning workload.

102 Danish Institute for Human Rights, Report from the Roundtable of National Human Rights Institutions on the Issue of Business and Human Rights, Copenhagen, 1-2 July 2008, 3 <https:// nhri.ohchr.org/EN/Themes/BusinessHR/Pages/AppA_NHRI_HRB_Roundtable_072008.pdf> (accessed 17 July 2020).

103 For some of the practical obstacles NHRIs face, see Haász (n 46) 183-184. 
A second challenge concerns the legal restrictions some NHRIs face when addressing the private sector. As pointed out above, NHRIs are increasing looked at as a potentially potent actors to facilitate access to remedy. Brodie has pointed out that the reality is that the potential contribution of NHRIs can be overstated. ${ }^{104}$ Regarding access to remedy, some NHRIs have complaint-handling mechanisms and some have the power to conduct investigations but most NHRIs do not have the power to hand down enforceable, binding orders. Moreover, not all NHRIs have the mandate to address the private sector. A survey conducted by the Office of the High Commissioner for Human Rights (OHCHR) found that only 10 out of the 43 NHRIs that responded had jurisdiction to address the private sector. ${ }^{105}$ This is especially the case where a national ombudsperson is the designated NHRI. ${ }^{106}$ Whether NHRIs currently indeed significantly provide access to effective remedy in a narrow sense is thus rather doubtful. Nevertheless, in a broader sense, NHRIs can and do work on remedy-related issues. Moreover, NHRIs have been called upon to be creative and seek entry-point for business and human rights matters when their jurisdiction is restricted to addressing the State. ${ }^{107}$

A third major challenge that NHRIs face when dealing with multinational corporations concerns the territorial reach of their mandate. Most NHRIs have been established to monitor State compliance with its human rights obligations within the State. This restricts the room NHRIs have to address human rights abuses taking place outside of their country. By its very nature, multinational business accedes national borders. The national mandate of NHRIs may pose significant hurdles for NHRIs to effectively address transnational corporate activity. NHRIs from different countries have collaborated to overcome these hurdles. ${ }^{108}$

In sum, a lot of emphasis has been placed on the potential role NHRIs can play in providing access to remedy. Yet, practice to date shows that the number of NHRIs that have the mandate to provide access to remedy in a strict, sense, ie actually complaint-handling is quite limited. Moreover, most NHRIs face restrictions when it comes to addressing the private sector in general or corporate

104 Brodie (n 48) 246.

105 OHCHR, Business and Human Rights: A Survey of NHRI Practices, Results from a survey distributed by the Office of the United Nations High Commissioner for Human Rights (2008).

106 See Reif (n 30) 618-620.

107 Edinburgh Declaration (2010), Berlin Report (2019).

108 For example, the NHRIs of Germany and Colombia have cooperated monitoring both ends of the supply chain in the coal-sector. See Business \& Human Rights. Trans-national NHRI cooperation between Colombia and Germany, German Institute for Human Rights <https://www.institutfuermenschenrechte.de/fileadmin/user_upload/PDF-Dateien/Sonstiges/Trans-national_NHRI_ cooperation_between_Colombia_and_Germany_Poster_DINA4.pdf> accessed 20 July 2019. 
activities of a transnational nature in particular. However, access to remedy can also be seen in a broader sense as promoting better access to remedy in this area for example, by offering advice to victims or to government on draft legislation. When seen from this perspective, NHRIs have undertaken multiple activities to facilitate access to remedy.

Thus NHRIs may face several hurdles when engaging with corporations to address harmful corporate activity. Yet, the draft Optional Protocol to the BHR-Treaty provides for a significant role for NHRIs in promoting compliance, monitoring and implementing the treaty. In the next section, the envisioned role will be explored against the background of the above analysis of current state of affairs and the existing challenges. As will be explained the envisioned role raises quite some questions but formalizing a role for NHRIs in the business and human rights field holds potential as will be explained in Section 6 where it is argued this institutional innovation can address a missing link in the emerging business and human rights governance architecture.

\section{The Optional Protocol to the Business and Human Rights Treaty: The Role of NHRIs}

How does the draft Optional Protocol to the BHR-Treaty envision the role of NHRIs and how should this proposal be evaluated also in light of the discussion of the current obstacles NHRIs face? In accordance with Article 1 of the Optional Protocol, each State Party shall designate or establish, within 2 years a National Implementation Mechanism (NIM) to promote compliance with, monitor and implement the treaty on business and human rights. With a reference to the Paris Principles States parties are required, inter alia, to ensure the independence of the NIM and its officers and ensure necessary resources. ${ }^{109}$ According to the draft Optional Protocol, the NIM would have three key functions:

(i) raising awareness of the BHR-Treaty at the domestic level;

(ii) conducting due diligence reviews;

(iii) running a mediation process.

109 Article 2 Optional Protocol (2018). 
The first task of the NIM would be to make the treaty content known to the general public, business and victims; to cooperate with other national institutions, foreign NIMs and civil society organizations and to raise awareness on the implementation of the treaty ${ }^{110}$ and to make recommendations to a State Party's competent authorities. ${ }^{111}$ Beyond these awareness-raising activities, which fit well with the promotional tasks NHRIs have, the NIM would have quite far-reaching investigatory and review-competences. According to Article 5, the National Mechanism would be granted the competence to conduct reviews on the implementation of due diligence obligations as provided in the BHR-Treaty. Article 9 of the zero draft of the BHR-Treaty provides that

State Parties shall ensure in their domestic legislation that all persons with business activity of transnational character within such States Parties' territory or otherwise under their jurisdiction or control shall undertake due diligence obligations throughout such business activities $[\ldots] .{ }^{112}$

A very broad range of actors may request the NIM to conduct a review of the due diligence obligations: 'victims, natural or legal persons conducting business activities of a transnational character, or all other persons with a legitimate interest'. ${ }^{113}$ To prevent human rights violations in the context of business activities, the OP states that NIMs would have the power to request all necessary information from a State Party in relation to the implementation of the treaty which may include reports on human rights matters provided by natural or legal persons under their jurisdiction. Presumably, the power to request all necessary information refers to the information corporations would be required to produce in the context of their due diligence obligations. The article refers to information

110 By a) Responding to enquiries by victims, business [enterprises] and the general public, as appropriate; b) Submitting recommendations to relevant national authorities for improving the implementation of the [legally binding instrument and the prevention of human rights [violations] in the context of any business activities of a transnational character; c) Submit proposals and observations on existing or draft legislation [on matters relating to the implementation of the [legally binding instrument].

111 Article 3 Optional Protocol (2018).

112 This due diligence obligation is also included in the second, revised draft treaty released in July 2019. The obligation has been reformulated as follows: 'States parties shall adopt measures necessary to ensure that all persons conducting business activities, including those of a transnational character, to undertake due diligence [...]'. See article 5 (2), Draft BHR Treaty (July 2019). The obligation now applies to all corporations and not only those that undertake business activities of a transnational character. Moreover, the obligation to take legal measures has been replaced by the obligation to take measures. For analysis of the proposed text in 2019 see <www. businessandhumanrights.org> accessed 17 July 2020.

113 Emphasis added. Article 5 Optional Protocol (2018). 
concerning internal policies, outcomes and indicators of environmental and human rights impact assessments. ${ }^{114}$ The NIM would also have the power to request such information from other State Parties in the case of transnational business activity. ${ }^{115}$ This addresses the restrictions most NHRIs now face in addressing the transnational activities of multinational enterprises. To conduct due diligence reviews, the national implementation mechanism would have the competence to visit and inspect business enterprise's facilities, and conduct joint visits and inspections with other NIMs to monitor the implementation and follow up of due diligence plans or policies. ${ }^{116}$ Provisions that would equip the NIM to request and cooperate with mechanisms in other countries would overcome the jurisdictional restraints NHRIs currently often face in the business and human rights field. In case of non-compliance, the NIM would provide recommendations to natural or legal persons conducting business activities in order for it to bring its operation into compliance, or inform the competent authorities. ${ }^{117}$

By granting the NIM the competence to review the implementation of due diligence, the Optional Protocol aims to address an important gap in the current business and human rights governance structures. As pointed out by Bernaz, increasingly, 'corporations are required to report on their human rights performance but there is no consequence for poor reporting, and no systematic process to check whether corporations have done enough, or even the veracity of those reports. Instead, states rely on civil society scrutiny. ${ }^{, 118}$ As will be discussed in Section 7, this relates to what some scholars have identified as 'a principle deficiency ${ }^{119}$ of the UNGPs, the failure to institutionalize, to provide tools to empower the participatory rights and roles of civil society. Institutionalizing this role by granting the NIM the power to conduct such reviews would be a significant step

114 Article 4, 1 (A) Optional Protocol (2018). As pointed out by Bernaz, this provision assumes that States would store all such information. Nadia Bernaz, A Commentary of the Draft Optional Protocol to the Business and Human Rights Treaty (1 October 2018), Business as Usual <http:// www.http://rightsasusual.com/?p=1292> accessed 17 July 2020.

115 Article 4 Optional Protocol (2018).

116 Article 5 (2) Optional Protocol (2018).

117 Article 5 (3) Optional Protocol (2018).

118 Bernaz (n 115).

119 Tara J Melish, 'Putting 'Human Rights' Back into the UN Guiding Principles on Business and Human Rights: Shifting Frames and Embedding Participatory Rights' in Cesar Rodriguez-Garavito (ed), Business and Human Rights: Beyond the Beginning (Cambridge University Press, 2017) 76, 80. For a similar argument see also the chapter in the same book written by Cesar Rodriguez-Garavito, 'Business and human rights: Beyond the Beginning', 1-46. Furthermore see: Tara Melish and Errol Meidinger, 'Respect, Protect, Remedy and Participate: New Governance' Lessons for the Ruggie Framework' in Radu Mares (ed), The UN Guiding Principles on Business and Human Rights: Foundations and Implementation (Martin Nijhoff Publishers 2012) 304. 
towards bridging the governance gap that currently exists. In the next section, it will be explained how the proposal to establish national implementation mechanisms fits in a broader development towards institutional innovation in human rights governance.

The Optional Protocol also carves out a role for the NIM in providing access to remedy. National Mechanisms may have the competence 'to receive and consider complaints of human rights violations alleged to have been committed by natural or legal persons conducting business activities of a transnational nature brought by victims, their representatives or other interested parties'. ${ }^{120}$ In the course of such proceedings the NIM may, inter alia, request and receive all information, conduct visits and receive testimony. ${ }^{121}$ Subsequently, the national mechanism will offer its good offices in order to reach an amicable settlement and, if reached, monitor compliance with this settlement. ${ }^{122}$ This function is similar to the mediation role that the OECD National Contact Points currently undertake.

In sum, the Optional Protocol foresees a role for NHRIs as National Implementation Mechanisms in the future BHR-Treaty which would entail awarenessraising, a task NHRIs are familiar with, and quite far-reaching powers to conduct reviews of human rights due diligence obligations. Moreover, the future NIM would have a role as mediator in business and human rights conflicts. Besides the review and mediation by the NIM, the Optional Protocol relies on international supervision by establishing an individual complaint procedure mirroring the procedures of traditional international human rights treaties. According to Article 8, States Parties to the draft Optional Protocol recognize the competence of the committee supervising compliance with the business and human rights treaty, 'to receive and consider communications from or on behalf of individuals or group of individuals and [those parties that have reached an amicable agreement], with regards to human rights violations in the context of business activities of transnational character under the jurisdiction of a State Party [...]. ${ }^{123}$ A rather novel element is that the supervisory body will have the competence to not only invite concerned States Parties but also 'the involved person conducting business activities of a transnational character to co-operate in the examination of the communications received'. ${ }^{124}$ After the examination, the committee will send its findings and recommendations to the State Party but also to involved person

120 Emphasis added. Again, the range of actors that can turn to the NIM is very broad. Article 6 (1) Optional Protocol (2018).

121 Article 6 (3 a-d) Optional Protocol (2018).

122 Article 6 (4) Optional Protocol (2018).

123 Article 8 (1) Optional Protocol (2018).

124 Article 10 Optional Protocol (2018). 
conducting the business activity. ${ }^{125}$ Directly involving corporations in the UN supervisory proceedings is potentially groundbreaking.

The reception of the Optional Protocol was lukewarm. Whereas employers' organizations criticized the Optional Protocol for going too far, several civil society organizations felt the Optional Protocol does not go far enough. The International Organization of Employers (IOE) criticized the unclear status of the NIM pointing out the competence to conduct visits and inspections to business' facilities is 'very vague and problematic' as 'only competent national authorities should have the authority to visit and inspect company facilities' ${ }^{126}$ However, it should be pointed out that many NHRIs currently already have similar investigatory powers. The employers also raised many practical issues such as the question how a NIM would deal with the sheer number of due diligence reviews it could potentially be confronted with. ${ }^{127}$

NGOs have been especially dismissive of the fact that enforcement is left to an international supervisory body of experts and national implementation mechanisms. Relying on mediation will not provide better access to remedy and would in fact even weaken the provisions in the BHR-Treaty it is argued. NGOs would like to see the NIM have standing to bring business and human rights cases before a court of law. ${ }^{128}$ They argue that the focus in the Optional Protocol is too much on conciliation and mediation and no reference is made to the protection function of NHRIs as mentioned in the Paris Principles, especially the possibility of hearing complaints or petitions of human rights violations, and transmitting them to the competent administrative and judicial national authorities. ${ }^{129}$

125 Article 11 (2) Optional Protocol (2018).

126 International Organisations of Employers (IOE), International Chamber of Commerce, Business at OECD, BusinessEurope, 'Business response to the Zero Draft Legally Binding Instrument to Regulate, in International Human Rights Law, the Activities of Transnational Corporations and Other Business Enterprises ("Zero Draft Treaty") and the Draft Optional Protocol to the Legally Binding Instrument ("Draft Optional Protocol") Annex October 2018' <https://cdn.iccwbo.org/ content/uploads/sites/3/2018/10/icc-joint-business-response-zero-draft-2018.pdf> accessed 17 July 2020.

127 IOE and other (2018) p 24.

128 Raphaela Lopes (Justiça Global) and Arnold Kwesiga (Initiative for Social and Economic Rights), members of ESCR-Net, 'What the Zero Draft and Protocol Lack: Meaningful Access to Justice - a Global South Perspective', <https://www.business-humanrights.org/en/what-the-zerodraft-and-protocol-lack-meaningful-access-to-justice---a-global-south-perspective> accessed 17 July 2020.

129 Gabriela Ketzel and Andres Lopez Cabello, Centro de Estudios Legales y Sociales (CELS), Daniel Cerqueira Due Process of Law Foundation (DPLF), 'Optional Protocol: Blog. First impressions on the Draft Optional Protocol to the Legally Binding Instrument regulating the activities of transnational corporations and other business enterprises' <https://www.escr-net.org/sites/ default/files/advocacy_position_papers_igwg2018.pdf> accessed 17 July 2020. 
It is true that the track-record of the international human rights supervisory bodies is less than glorious when it comes to monitoring State compliance. Yet the fact that a draft for an international treaty follows the same supervisory structures as other international treaties hardly comes as a surprise. The drafters of the Optional Protocol have stressed the conciliatory role for NHRIs. Other, possibly more adjudicative functions are not explicitly mentioned. In light of the continuing problems victims of corporate-related human rights abuse face, it is understandable that the lack of attention for access to remedy was met with disappointment by human rights advocates. However, it is argued here that dismissing the potential of National Implementation Mechanisms in the field of business and human rights altogether may be a bit too hasty. Institutionalizing a role to review compliance with due diligence obligations could be a potent step as such a formal role is presently missing in the emerging business and human rights architecture. Currently, monitoring corporate respect for human rights is mostly left to civil society. Implementing this idea in practice no doubt will pose challenges ${ }^{130}$ but mandating an organization with the power to review due diligence obligations is a significant step towards closing existing governance gaps.

\section{Joining the Ranks of a New Generation of Human Rights Instruments}

With the requirement to establish a national implementation mechanism, the draft Optional Protocol to the future business and human rights treaty joins the ranks of a new generation of human rights treaties which have triggered institutional innovation. These treaties have taken a more 'intrusive governance architecture via intermediation, ${ }^{, 131}$ compared to traditional human rights treaties. Where conventional human rights treaties rely on monitoring compliance through international expert bodies that monitor State compliance by means of reporting and constructive dialogue, the new generation of human rights treaties has added an additional monitoring structure at the domestic level. The obligation to set up

130 Bernaz points out some challenges of mostly a practical nature: the fact that most such a review process will be met with suspicion on the side of corporations, questions regarding how detailed such a review will be and how to ensure that the Mechanism is staffed with people with a good understanding of how corporations function. And what will happen if the Mechanism has (allegedly) not complied with the minimum requirements of due process of law? Bernaz (n 115). 131 Pegram (n 14) 226. 
National Implementation Mechanisms mirrors comparable obligations under the Optional Protocol to the Convention Against Torture (OPCAT) ${ }^{132}$ and in the Convention on the Rights of the Persons with a Disability (CRPD). ${ }^{133}$ Similar institutional innovations can be found in treaties in other fields such as chemical weapons ${ }^{134}$ and tobacco ${ }^{135}$. Here, the focus will be on the human rights treaties that have incorporated an obligation to establish a formal role for an intermediary to promote, monitor and implement the treaty. As will be discussed, with the introduction of a new tier of domestic in-between actors connecting international top down rules with bottom-up monitoring and participation, institutional innovation is taking place that incorporates certain features of experimentalist governance ${ }^{136}$ and new governance ${ }^{137}$ into traditional human rights treaties. De Burca, Keohane and Sabel identify a broader emerging development, which they label 'experimentalist governance' in various arenas of global governance, towards

a form of adaptive, open-ended, participatory, and information-rich cooperation in world politics in which the local and the transnational interact through the localized elaboration

132 For more information on the Optional Protocol to the Convention Against Torture and the National Preventive Mechanisms, see work by Rachel Murray, such as: The Optional Protocol to the UN Convention Against Torture (Oxford University Press, 2011).

133 For a detailed analysis of the development of this idea in CRPD and the role NHRIs should play, see: Gauthier De Beco, Article 33 (2) of The UN Convention on the Rights Of Persons With Disabilities: Another Role For National Human Rights Institutions? (2011) 29:1 Netherlands Quarterly of Human Rights 84 and Gauthier de Beco (ed), Article 33 of the UN Convention on the Rights of Persons with a Disability. National stuctures for the implementation and monitoring of the Convention (Brill/Nijhoff, 2013).

134 The Chemical Weapons Convention obliges States Parties to establish a National Authority (Article VII (4)). This Convention has quite an intrusive character as States Parties, in accordance with Article IX agree to short-notice challenge inspections, which can be conducted at any location in any State Party about which another State Party has concerns regarding possible noncompliance with the treaty.

135 Under the WHO Framework Convention on Tobacco Control, Article 5 (2) requires the formation of intersectoral coordinating mechanisms. These mechanisms are not as intrusive as OPCAT or the entities under the Chemical Weapons Convention but are illustrative of another significant feature of such localized authorities: the recognition of the need to address policy fragmentation and break down departmental silos on certain issues. This is also characteristic for the business and human rights field.

136 For more on experimentalist governance see Grianne De Burca, Robert O Keohane and Charles Sabel, 'New Modes of Pluralist Global Governance' (2013) 45:3 NYUJ Int L \& Pol 723.

137 For more on new governance, see Kenneth W Abbott and Duncan Snidal, 'Strengthening International Regulation Through Transnational New Governance: Overcoming the Orchestration Deficit' (2009) 42:2 Vanderbilt Journal of Transnational Law 501. For more on the differences and commonalities between experimentalist governance and new governance, see Grainne De Burca, 'New Governance and Experimentalism: An Introduction' (2010) WISLRev 227. 
and adoption of transnationally agreed global norms, subject to periodic revision in light of knowledge locally generated. ${ }^{138}$

Implementation of broadly framed goals is left to lower-level entities that have knowledge of local conditions and can adapt global norms to the local context. ${ }^{139}$ They discuss several examples that illustrate this development, among which CRPD. ${ }^{140}$

Before discussing how the proposal to establish a National Implementation Mechanism can potentially address a gap in the emerging business and human rights regulatory architecture, similar institutional arrangements under CRPD and OPCAT will first be discussed. How does the obligation to create a national mechanism in the Optional Protocol to the BHR-Treaty compare to the provisions in OPCAT ${ }^{141}$ and CRPD?

According to OPCAT States Parties are required to:

[...] maintain, designate or establish, at the latest one year after the entry into force of the present Protocol or of its ratification or accession, one or several independent national preventive mechanisms [NPMs] for the prevention of torture at the domestic level. [...]. ${ }^{142}$

To date, there are 68 designated NPMs. Like the Optional Protocol to the BHR-Treaty, OPCAT stresses the need for functional independence of the national mechanisms and refers to the Paris Principles which States must take into account

138 De Burca, Keohane and Sabel (n 137) 726-727. Experimentalist governance is what they identify as Mode III in global governance. Mode I refers to the traditional principle-agent regimes where States created international regimes to address global problems. Mode II refers to the departure from 'hierarchy as the structuring principle [...] and the spread of [...] novel forms of networked information exchange' ( $p$ 733). They mention public-private partnerships as examples of Mode II governance. Mode III is defined as: 'Experimentalist Governance describes a set of practices involving open participation by a variety of entities (public or private), lack of formal hierarchy within governance arrangements, and extensive deliberation throughout the process of decision making and implementation' ( $\mathrm{p} 738$ ).

139 De Burca, Keohane and Sabel (n 137) 738-739.

140 The other examples De Burca, Keohane and Sabel address are: the Inter-American Tropical Tuna Commission and the Montreal Protocol on Substances that depletes the Ozone Layer.

141 For more information on the Optional Protocol to the Convention Against Torture and the National Preventive Mechanisms, see work by Rachel Murray, such as: The Optional Protocol to the UN Convention Against Torture (Oxford University Press, 2011).

142 Article 17 OPCAT. 
when designing their national mechanisms. Consequently, the majority of these national mechanisms are NHRIs. ${ }^{143}$ The independent NPMs must have unrestricted access to places of detention to 'regularly examine the treatment of the persons deprived of their liberties' and must have the ability to engage with people in detention. ${ }^{144}$ NPMs can also engage in awareness-raising activities. NPMs have formal linkages with the Sub-committee on the Prevention of Torture (SPT) which has a uniquely far-reaching mandate in the human rights field to conduct countryvisits in places of deprivation of liberty. ${ }^{145}$ In his analysis of OPCAT, Pegram identifies some of the benefits of the establishment of the preventive mechanisms at the national level. As he points out, 'NPMs provide the SPT with an additional lever to enhance the legitimate authority of the OPCAT-architecture, as well as consistency in application of standards at the local level'. ${ }^{146}$ The NPM also offers a way to 'enagage in orchestration activities with other torture prevention actors, including civil society and media'. ${ }^{147}$ An effective NPM, according to Pegram, can 'not only advance compliance with torture prevention standards, but also advance compliance through socialization of domestic actors'. ${ }^{148}$ In other words, the NPM are key players not only to monitor State compliance but to involve all stakeholders in the implementation of the norms. This reflects elements of new governance approaches which typically seek to incorporate new mechanisms of stakeholder participation.

The institutional requirements under OPCAT are more detailed and more intrusive than those of the national monitoring mechanism under CRPD. Article 33 CRPD stipulates that besides a 'focal point within government for matters related to the implementation of the Covenant ${ }^{149}$,

143 Designating NHRIs as the official NPM is not without challenges. For a discussion of these see, inter alia, Association for the Prevention of Torture, 'National Human Rights Institutions as National Preventive Mechanisms: Opportunities and challenges', APT Briefings Series (December 2013) <https://www.files.ethz.ch/isn/175324/apt-briefing-on-nhris-as-npms-dec2013.pdf> accessed 17 July 2020 and The Relationship between Accreditation by the International Coordinating Committee of National Human Rights Institutions and the Optional Protocol to the UN Convention Against Torture, OPCAT Team University of Bristol (November 2008) <http:// www.bristol.ac.uk/media-library/sites/law/migrated/documents/iccaccreditationandnpms. pdf> accessed 17 July 2020.

144 Arts 19 and 20 OPCAT.

145 See, Article 14 OPCAT.

146 Pegram (n 14), 630.

147 Pegram (n 14), 630.

148 Pegram (n 14) 630.

149 Art 33 (1) CRPD. 
[...] States Parties shall [...] maintain, strengthen, designate or establish within the State Party, a framework, including one or more independent mechanisms [...] to promote, protect and monitor implementation of the present Convention. ${ }^{150}$

Different from the NIM in the Optional Protocol to the BHR Treaty, CRPD does not speak of implementation as one of the tasks of the National Monitoring mechanism. Rather this mechanism will promote, protect and monitor the treaty. To promote disability rights, the NMM needs to foster an acceptance of the values underlying CRPD. The national mechanism thus plays an important role in the socialization of the norms in CRPD. To protect disability rights requires the NMM to help disabled persons claim their rights when they deem they are violated. Monitoring CRPD implies the evaluation of compliance of both legislation and practice with disability rights. Like OPCAT and the OP-BHR Treaty, CRPD refers to the Paris Principles. ${ }^{151}$ As explored by The Beco, in light of their mandate NHRIs are well placed to take on the tasks of NMM under article 33 CRPD. ${ }^{152}$ In 2017, 32 equality bodies and NHRIs were designated as NMM to promote, protect and monitor the implementation of the CRPD in 29 countries. ${ }^{153}$ Different from OPCAT and the draft Optional Protocol to the BHR-Treaty this obligation is not in a separate protocol but part of the main treaty text of CRPD. The central motto of the disability rights movement 'nothing about us without us', explains the importance attached in CRPD to giving a voice to the rightsholders and institutionalizing this by means of a national monitoring mechanism. CRPD is unique in that it brings in beneficiaries as active participants into the monitoring process. CRPD, requires civil society, in particular persons with disabilities and their representative organizations, to be involved and participate fully in the monitoring process. ${ }^{154}$ These participatory features are why De Burca, Keohane and Sabel view CRPD as an example par excellence of experimentalist governance. ${ }^{155}$ Besides participation another central element of experimentalist governance is the learning from continuous feedback and peer-review. This can be found in CRPD in the provision for the holding of an annual Conference of the Parties. The peer review element is

150 Emphasis added. Art 33 (2) CRPD.

151 See Meredith Raley, 'The Paris Principles and Article 33 (2) of the CRPD, Disability and Human Rights (11 October 2011) where she explains that Article 33 (2) CRPD was drafted with NHRIs in mind.

152 De Beco (n 134) 95-97. De Beco also points out some of the challenges and suggest that some of the tasks may be shared. The flexibility of Article 33 allows for a division of tasks and the application of the Paris Principles to other bodies than NHRIs.

153 Survey ICC.

154 Art 33 (3) CRPD.

155 De Burca, Keohane and Sabel (n 137) 749-763. 
also found in the BHR-Treaty which likewise provides for a Conference of States Parties. ${ }^{156}$

Both CRPD and OPCAT have created novel national mechanisms that localize authority as part of their governance architecture. There are some striking differences. The NPM under OPCAT is more intrusive compared to the national mechanism under CRPD. Torture prevention is much more adversarial than disability rights which explains these differences. The proposed National Implementation Mechanism under the OP to the BHR-treaty resembles the institutional innovation in CRPD and OPCAT. Different from CRPD, where the National Monitoring Mechanism is tasked to 'promote, protect and monitor' the treaty, the National Implementation Mechanism on business and human rights would seem to go a lot further. Besides promoting and monitoring, the NIM would have an active task in implementing the BHR-Treaty. In this sense the proposed NIM would have more intrusive tasks alike the NPMs under OPCAT. One of the main tasks of the NIM would consist of reviewing corporate due diligence obligations, a task, as mentioned previously, currently falls mostly on civil society watchdogs.

While it is probably too early to tell whether the governance regimes that display some experimentalist or new governance features are adequately addressing the problems they are meant to tackle, it is argued that the institutionalization at the national level has the potential to be a constructive development. ${ }^{157}$ The discussion of the institutional arrangements under OPCAT and CRPD bring forward some of the potential benefits of introducing formalized structures at the national level. These benefits include the creation of avenues to include other actors in the governance of the issue at hand, enhancing informal spaces for dialogue, socialization of norms and adding legitimacy to the international standards and structures. Increasingly NHRIs are looked at to take up such a role as national monitoring body. In the General Observations which interpret the Paris Principles, such a role for NHRIs is recognized. General Observation 2.8 assesses NHRIs as National Preventive and National Monitoring Mechanisms. The next section discusses how the creation of a national mechanism might bridge an existing regulatory gap in the business and human rights field.

156 Art 11 (5) Zero Draft (2018). The revised 2019 draft provides for this in Article 13 (5).

157 De Burca, Keohane and Sabel (n 137) 728. 


\section{A National Implementation Mechanism: The Missing Link in Business and Human Rights?}

The UN Guiding Principles have proven a catalyst for a growing business and human rights governance architecture. The UNGPs embody a new governance approach, ie an approach that decenters the State, emphasizing the role of the State as an 'orchestrator"158 promoting and empowering a broader network of public, private and civil society actors. However, the UNGP have been critiqued for failing to formally empower civil society as a key actor in such polycentric new governance. Melish and Meidinger have pointed out this missing link in the emerging governance architecture in the domain of business and human rights. ${ }^{159}$ In their analysis they argue that the weak point of the UNGPs is the lack of formalization of participation: '[although the guiding principles do call for transparency and participation in the conduct of corporate due diligence responsibilities, such participation is not required under the framework; nor can it be asserted by civil society groups as a "right" conferred under the framework."160 Melish and Meidinger reach the conclusion that the UN Framework is conceptually flawed by not explicitly recognizing a right to participate for stakeholders. They state that:

under the current conceptual framework, a business can legitimately claim that it need not allow for civil society participation in external monitoring of any of the aforementioned due diligence activities. This apparent corporate right of control over who has access to relevant information for human rights monitoring and impact assessment and who can speak on behalf of communities in voluntary consultation processes is a major operational gap in the Ruggie framework. Indeed, corporate actors are unlikely, at least in the short term, to see external monitoring of their operations on the human rights of affected communities as consistent with their economic interests. ${ }^{161}$

Melish and Meidinger argue that '[a]dditional actors, with distinct ways of levering power over corporate and state conduct must be explicitly brought into the framework for it to be effective in closing the current governance gaps. ${ }^{162}$ The proposal to establish a National Implementation Mechanism can be seen as a step in that direction. Under the Optional Protocol, a broad range of actors, including

158 Kenneth Abbott, Philipp Genschel, Duncan Snidal and Bernhard Zangl (eds), International Organizations as Orchestrators (Cambridge University Press, 2015).

159 Melish and Meidinger (n 121) 303-336.

160 Melish and Meidinger (n 121) 331.

161 Melish and Meidinger (n 121) 331.

162 Melish and Meidinger (n 121) 329. They propose a fourth pillar should be added to the three pillars 'Protect, ‘Respect, Remedy’ Framework, the pillar 'Participate'. 
'victims, natural or legal persons conducting business activities of a transnational character, or all other persons with a legitimate interest', would have standing to request the NIM to conduct a review of the due diligence obligations. ${ }^{163}$ Moreover, an equally broad range of 'interested parties' may submit 'complaints of human rights violations alleged to have been committed by natural or legal persons conducting business activities of a transnational nature', to the attention of the NIM. Such complaints could prompt investigations and meditation. A national mechanism with this mandate would offer an avenue for civil society and other stakeholders, formalizing their participation in the business and human rights domain. The benefits identified in relation to OPCAT and CRPD could also apply in the business and human rights context. The NIM could be a platform to enhance spaces for dialogue including other actors in the governance of business and human rights. The existence of a national mechanism could further the socialization of norms such as human rights due diligence and add overall legitimacy to the treaty. Moreover, the issues in the business and human rights field are scattered across policy areas and government departments. The monitoring tasks of the NIM may help break down departmental silos and address policy fragmentation. Further research is required into the conditions under which national governance structures can best effectuate these goals. ${ }^{164}$

Besides these potential benefits there are a range of challenges. One central concern is independence. Human rights governance is notoriously challenging as the State is both the regulator and the target. There is a risk of capture, as pointed out by Pegram, that, as it is left up to States to design their own national mechanisms increases, the independence of such mechanisms will be under strain. ${ }^{165}$ Reluctance to be monitored might constitute a threat to the independence of national mechanisms. Besides safeguards in the law to protect these mechanisms, Pegram points out the importance that intermediates monitor and support each other. ${ }^{166}$ Under OPCAT, the Sub-Committee for the Prevention of Torture actively monitors the independence of the NPMs and the Committee on the Rights of Persons with a Disability has drafted guidelines on the form and functioning of the

163 Article 5 Optional Protocol (2018).

164 See the study by Pegram into the role of intermediates in governance investigating how and under what conditions effective what he calls 'regulatory stewardship' can be institutionalized. Pegram (2017) p 233.

165 Pegram (n 44).

166 Pegram (n 44) 230-233. 
National Monitoring Mechanisms. ${ }^{167}$ It is conceivable that the committee supervising the BHR-Treaty would be involved in policing the functioning and the independence of the National Implementation Mechanisms. Moreover, the accreditation-process of GANHRI where NHRIs by means of peer review can monitor and support the independence of other NHRIs can also protect a national mechanism against capture. ${ }^{168}$

There are more potential challenges of a practical and political nature to operationalizing the idea of NHRIs as National Implementation Mechanisms. The question may be raised whether it the prospect of such a mechanism might further undermine willingness to sign and ratify the Future Business and $\mathrm{Hu}$ man Rights Treaty where political support for the binding instrument is already rather low among industrialized countries. Moreover, operationalizing the idea of NHRIs as NIM in the business and human rights field will require mandates to be adjusted and involved regional and subnational commission in many cases. As already mentioned supra, NHRIs face considerable challenges when it comes to funding. Adding yet another task to their mandate beyond their basic responsibilities would require considerable expenditures to prevent underfunding.

It can be concluded that, despite a range of practical and political hurdles to be overcome, novel formal roles for NHRIs as intermediary bodies in the business and human rights domain hold promise. In further developing this idea in the Optional Protocol to the BHR-Treaty, the drafters would be well advised to take on board the insights from the actual functioning of similar institutional arrangements in OPCAT and CRPD.

\section{Conclusion}

The future business and human rights treaty is breaking new ground in many ways and has sparked a lot of discussion. The institutional innovation that the draft Optional Protocol introduces has received relatively little attention. Yet it is concluded here that the proposals in the Optional Protocol hold potential to address a missing link in the current business and human rights governance architecture. The BHR Treaty establishes a conventional international human rights

167 CRPD, Committee on the Rights of Persons with Disabilities Draft Guidelines on the establishment of Independent Monitoring Frameworks and their participation in the work of the Committee (20 April 2016) $<$ https://ohchr.org/EN/HRBodies/CRPD/Pages/DraftGuidelinesestablishmentindependentmonitoring. aspx $>$ accessed 17 July 2020.

168 This process of mutual monitoring and support is what Pegram refers to as regulatory stewardship. Pegram (n 44). 
treaty-monitoring committee of experts but also a novel national level monitoring and implementation body. The Protocol carves out a role for these National Implementation Mechanisms which would entail awareness-raising, and quite farreaching powers to conduct reviews of human rights due diligence obligations. This could potentially provide some 'teeth' to the increasing expectations that corporations will conduct due diligence. Policing corporate conduct is currently mostly left to civil society. The business and human rights architecture misses a formal role for actors to monitor corporate and State behavior. Besides institutionalizing this monitoring function, the future NIM would have a role as mediator in business and human rights conflicts. Access to remedy for victims of corporate related human rights abuse continues to be of major concern. In light of the little progress made in this field, it is perhaps understandable that the institutional arrangements in the Optional Protocol have been met with some disappointment by human rights advocates. The Optional Protocol does not provide for direct access to remedy. However, it is concluded that the idea of a National Implementation Mechanism must not be dismissed too hastily. The institutional innovation fits in a broader nascent development, introduced in a number of other 'new generation treaties', which institutionalize a top down with a bottom up approach aiming to address the disjuncture between rules and practice. The Optional Protocol addresses the current void in business and human rights by officializing participation of stakeholders, levering power over corporate and State conduct. Moreover, a national mechanism may further the socialization of human rights due diligence, address fragmentation in policy and enhance the overall legitimacy of the BHR-treaty. By referring to the Paris Principles it is clear that the drafters of the Optional Protocol have NHRIs in mind to take up this role of NIM. This follows an increasing recognition of NHRIs as relevant bodies in the quest for accountability in business and human rights and there are mounting expectations, especially regarding access to remedy. NHRIs are increasingly addressing business and human rights matters albeit in a rather piecemeal fashion. It can be argued that the potential of NHRIs in this field has yet to be fully realized. The proposals in the Optional Protocol are a significant development to strengthen their role. NHRIs are particularly well placed to take on the proposed role given their localized knowledge and independence which finds protection in law and peer-review. Working under a formal mandate would increase the impact of NHRIs as significant 'in-betweens' in the business and human rights space. 